\title{
KONSEP DAN PENGEMBANGAN PENDIDIKAN KARAKTER PADA PEMBELAJARAN BIOLOGI DI SMA KABUPATEN LABUHANBATU UTARA
}

\author{
Concept And Development Of Character Education In Biology Learning In SMA \\ District North Labuhanbatu
}

\author{
Ika Chastanti \\ Pendidikan Biologi Sekolah Tinggi Keguruan dan Ilmu Pendidikan \\ Yayasan Universitas Labuhan Batu, Kabupaten Labuhanbatu, Sumatera Utara, Indonesia \\ Koresponden: chastanti.ika@gmail.com
}

\begin{abstract}
Abstrak
Penelitian ini bertujuan mendeskripsikan pemahaman guru, strategi pembelajaran dalam implementasi pendidikan karakter dan kendala dalam implementasi pendidikan karakter siswa SMA di Kabupaten Labuhanbatu Utara. Penelitian ini dilakukan dengan menggunakan pendekatan kualitatif. Teknik pengumpulan data pada penelitian ini adalah dengan melakukan In-depth Interview (Wawancara mendalam) dengan guru kelas dan guru mata pembelajaran, kepala sekolah, pengawas sekolah, dan siswa. Data yang telah dikumpulkan sebagai hasil wawancara dan observasi yang tersusun dalam bentuk catatan lapangan hasil wawancara dan catatan lapangan hasil obsevasi, kemudian dianalisis melalui tiga tahapan kegiatan yang terjadi secara bersamaan yaitu : reduksi data, penyajian data dan penarikan kesimpulan/verifikasi. Pendidikan karakter memiliki 3 aspek yaitu moral knowing, moral feeling, dan moral action. Pendidikan karakter sudah mulai diintegrasikan di dalam kurikulum di semua jenjang pendidikan di kabupaten Labuhanbatu Utara. Pembinaan karakter termasuk dalam materi yang harus diajarkan dan dikuasai serta direalisasikan oleh siswa dalam kehidupan sehari-hari. Permasalahannya, pendidikan karakter di sekolah selama ini baru menyentuh pada tingkatan pengenalan nilainilai, dan belum ada pada tingkatan internalisasi dan tindakan nyata dalam kehidupan sehari-hari. Untuk mewujudkan pendidikan karakter dibutuhkan guru yang memiliki pemahaman tentang karakter.
\end{abstract}

Kata kunci : Pendidikan karakter, konsep karakter, pengembangan karakter

\begin{abstract}
This study aims to describe the understanding of teachers, learning strategies in the implementation of character education and obstacles in the implementation of character education of high school students in North Labuhanbatu District. This research is done by using qualitative approach. Data collection techniques in this study were by conducting In-depth Interview (In-depth interview) with classroom teachers and learning eye teachers, principals, school supervisors, and students. The data that have been collected as the result of interview and observation are arranged in the form of field notes from interview and field observation result of observation, then analyzed through three stages of activities that occur simultaneously namely: data reduction, data presentation and conclusion / verification. Character education has 3 aspects of moral knowing, moral feeling, and moral action. Character education has begun to be integrated into the curriculum at all levels of education in North Labuhanbatu District. Character coaching is included in the material that students must be taught and mastered and realized in their daily lives. The problem is that character education in schools has only recently touched on the level of recognition of values and has not yet existed at the level of internalization and real action in everyday life. To realize the character education required teachers who have an understanding of the character.
\end{abstract}

Keywords: Character education, concept of character, character development. 


\section{PENDAHULUAN}

Tata krama, etika, dan kreativitas siswa saat ini disinyalir menurun akibat melemahnya pendidikan budaya dan karakter bangsa, padahal ini telah menjadi kesatuan kurikulum pendidikan yang diimplementasi dalam kegiatan belajar mengajar di sekolah (Muslich, 2011). Beberapa tindakan bullying yang sering terjadi di sekolah seperti mengejek dan menghina teman, mengucilkan dan memusuhi teman, mengancam jika tidak diberi contekan, mengambil barang teman dengan paksa serta melukai teman secara fisik (Gunawan, 2010).

Dunia pendidikan telah melupakan tujuan utama pendidikan yaitu mengembangkan pengetahuan, sikap, dan keterampilan secara simultan dan seimbang. Dunia pendidikan telah memberikan porsi yang besar untuk pengetahuan, tetapi melupakan pengembangan sikap/ nilai dan perilaku dalam pembelajarannya. Dunia pendidikan sangat meremehkan mata pembelajaran yang berkaitan dengan pembentukan karakter bangsa (Muslich, 2011).

Sekolah memiliki tanggung jawab moral untuk mendidik siswa menjadi pintar dan memiliki karakter. Tugas sekolah tidak hanya mengajar, tetapi juga mendidik sehingga siswa tidak hanya memiliki kemampuan kognitif tetapi juga memiliki karakter yang baik. Pendidikan karakter bukan hanya sekedar mengajarkan mana yang benar dan mana yang salah, akan tetapi lebih dari itu pendidikan karakter adalah usaha menanamkan kebiasaankebiasaan yang baik (habituation) sehingga peserta didik mampu bersikap dan bertindak berdasarkan nilai-nilai yang telah menjadi kepribadiannya, dengan kata lain, pendidikan karakter yang baik harus melibatkan pengetahuan yang baik (moral knowing), perasaan yang baik atau loving good (moral feeling) dan perilaku yang baik (moral action) sehingga terbentuk perwujudan kesatuan perilaku dan sikap hidup peserta didik (Anonim, 2011).

Pemerintah secara tegas telah membuat pengembangan karakter melalui pembelajaran, namun sampai dengan saat ini implementasinya belum memuaskan. Beberapa dinas pendidikan juga telah menggerakkan guru di masing-masing wilayah kabupaten atau kota, untuk turut membangun karakter siswa melalui semua mata pembelajaran, namun demikian gerakan ini belum optimal terimplementasikan dengan benar (Paidi, 2012).

Pendidikan biologi merupakan bidang ilmu yang memiliki tujuan agar setiap siswa memiliki kepribadian yang baik dan menerapkan sikap ilmiah serta mengembangkan potensi yang ada di alam untuk dijadikan sebagai sumber ilmu yang dapat diterapkan dalam kehidupan sehari-hari, dengan demikian biologi bukan hanya sekedar teori tetapi harus diterapkan melalui sikap siswa setelah belajar biologi. Pembangunan karakter melalui 
pembelajaran biologi bukan sesuatu yang baru. Sesuai dengan hakikat pembelajaran sains terdahulu adalah sangat memungkinkan melalui pembelajaran biologi akan dikembangkan sikap jujur, teliti, disiplin, tanggung jawab siswa, dan berbagai macam sikap sains lainnya.

Kegiatan penelitian ini menelusuri pendidikan karakter di tingkat SMA berhubungan dengan pemahanan terhadap konsep, implementasi dan bagaimana peluang pengembangannya ke depan. Penelitian akan difokuskan untuk memberikan jawaban terhadap permasalahan penelitian sehingga tujuan penelitian ini adalah: 1. Mendeskripsikan pemahaman guru biologi di SMA Kabupaten Labuhanbatu Utara terhadap konsep Pendidikan Karakter, 2. Mendeskripsikan strategi pembelajaran yang digunakan guru biologi dalam implementasi pendidikan karakter siswa SMA di Kabupaten Labuhanbatu Utara, 3. Mendeskripsikan kendala dalam implementasi pendidikan karakter siswa SMA di Kabupaten Labuhanbatu Utara.

\section{METODE PENELITIAN}

Penelitian ini dilakukan dengan menggunakan pendekatan kualitatif. Pendekatan kualitatif adalah suatu proses penelitian dan pemahaman yang berdasarkan pada metodologi yang menyelidiki suatu fenomena sosial dan masalah manusia. Pada pendekatan ini, peneliti membuat suatu gambaran kompleks, meneliti kata-kata, laporan terinci dari pandangan responden, dan melakukan studi pada situasi yang alami dengan pertimbangan bahwa data yang akan diperoleh dari penelitian ini merupakan data deskriptif kualitatif yaitu berupa katakata dan kalimat untuk menjabarkan hasil penelitian, kemudian peneliti melakukan analisis dari data yang ditemukan.

\section{Unit Analisis}

Penelitian ini menetapkan beberapa SMA di kabupaten labuhanbatu utara. Penetapan sekolah-sekolah tersebut mengacu pada pertimbangan bahwa sekolah dapat mendukung data yang diperlukan dalam penelitian.

\section{Teknik Pengumpulan Data}

Teknik pengumpulan data pada penelitian ini adalah dengan melakukan In-depth Interview (Wawancara mendalam) dengan guru kelas dan guru mata pembelajaran, kepala sekolah, pengawas sekolah, dan siswa untuk mengumpulkan data yang berkaitan dengan strategi pembelajaran yang digunakan guru dan kendala yang dialami sekolah dalam 
implementasi pendidikan karakter dan observasi yang dilakukan untuk melihat proses pembelajaran secara langsung.

\section{Teknik Analisis Data}

Data yang telah dikumpulkan sebagai hasil wawancara dan observasi yang tersusun dalam bentuk catatan lapangan hasil wawancara dan catatan lapangan hasil obsevasi, kemudian dianalisis melalui tiga tahapan kegiatan yang terjadi secara bersamaan yaitu : reduksi data, penyajian data dan penarikan kesimpulan/verifikasi (Milles dan Huberman, 1992).

\section{HASIL DAN PEMBAHASAN}

\section{Pemahaman Guru Biologi SMA di Kabupaten Labuhanbatu Utara Terhadap Konsep Pendidikan Karakter}

Guru memiliki peranan yang penting dalam penerapan pendidikan karakter agar siswa memiliki nilai karakter. Tetapi untuk penerapannya, guru akan mengalami kesulitan karena pendidikan karakter tidak mudah untuk diterapkan, butuh dukungan dari semua pihak seperti kepala sekolah, orang tua, masyarakat dan lingkungan. Sesuai dengan hasil wawancara dan observasi terhadap sejumlah guru SMA di Kabupaten Labuhanbatu Utara diketahui bahwa guru kurang memahami hakikat dan nilai karakter dalam pembelajaran. Menurut mereka pendidikan adalah proses menanamkan karakter baik pada siswa.

Guru biologi kurang mampu mengembangkan pendidikan karakter pada proses pembelajaran dan guru tidak mampu menunjukkan karakter yang bisa ditiru oleh siswa ketika di lingkungan sekolah. Guru seharusnya mampu mengintegrasikan pendidikan karakter dalam lingkungan sekolah, menjadi suri teladan bagi siswa dengan menunjukkan sikap yang bisa ditiru oleh siswa.

Pendidikan karakter dapat diibaratkan sebagai pembentukan seseorang menjadi body builder yang memerlukan latihan otot-otot akhlak secara terus menerus agar menjadi kokoh dan kuat. Guru harus bisa digugu dan ditiru oleh siswa. Oleh karena itu, setiap apa yang diucapkan di hadapan siswa harus benar dari sisi apa saja: keilmuan, moral, agama, dan budaya. Cara penyampaian pun harus menyenangkan dan beradab (Muslich, 2011).

Perkembangan seorang anak adalah mengembangkan pemahaman yang benar tentang bagaimana dunia ini bekerja, mempelajari "aturan main" segala aspek yang ada di dunia ini. 
Anak-anak akan tumbuh menjadi pribadi yang berkarakter apabila dapat tumbuh pada lingkungan yang berkarakter. Teori-teori tersebut menjelaskan bahwa strategi yang seharusnya dapat dilakukan untuk membentuk sikap peserta didik yang berkarakter adalah melalui pembiasaan dan pencontohan sikap (Wibowo, 2011). Pendidikan karakter adalah pendidikan budi pekerti plus yaitu yang melibatkan aspek teori pengetahuan (cognitive), perasaan (feeling), dan tindakan (action), tanpa ketiga aspek ini, maka pendidikan karakter tidak akan efektif dan pelaksanaanya harus dilakukan secara sistematis dan berkelanjutan. Dengan pendidikan karakter, siswa akan menjadi cerdas emosinya.

\section{Strategi Pembelajaran yang digunakan dalam Implementasi Pendidikan Karakter} Siswa SMA di Kabupaten Labuhanbatu Utara

Implementasi pendidikan karakter membutuhkan strategi pembelajaran yang sesuai dengan situasi sekolah dan siswa. Guru harus mampu memilih strategi pembelajaran agar perkembangan moral siswa meningkat. Terdapat 2 pendekatan alternatif yang bisa dilakukan oleh guru. (1) pendekatan pertama melihat karakter sebagai sesuatu yang tetap ada untuk pelatihan pembelajaran yang baik. pendekatan ini berarti bahwa ada sesuatu yang kecil yang dibutuhkan untuk pelatihan khusus pada etika atau dalam model kurikulum pendidikan moral yang jelas. Perkembangan karakter yang cukup adalah sebuah hasil yang efektif dalam pembelajaran karena harus dipercaya bahwa membentuk moral siswa akan lebih baik jika langsung ditangani oleh guru; (2) pendekatan kedua melihat bahwa pelatihan pembelajaran yang baik adalah kebutuhan tetapi tidak cukup untuk membentuk moral siswa secara efektif, mungkin pada beberapa point yang cukup tetapi lingkungan pergaulan siswa tidak terbentuk dengan baik (Lapsley dan Narvaez, 2006).

Ada 8 nilai pendidikan karakter yang bisa ditanamkan untuk siswa (1) Religius, (2) Peduli Kesehatan, (3) Mandiri, (4) Bersahabat atau Komunikatif, (5) Peduli Sosial, (6) Tanggung Jawab, (7) Peduli Kesehatan, dan (8) Peduli Lingkungan. Dari 8 nilai karakter ini diperlukan strategi khusus untuk menanamkan nilai karakter kepada siswa.

Strategi pembelajaran yang digunakan guru biologi pembelajaran adalah metode ceramah yaitu dengan hanya menyampaikan materi pembelajaran biologi dan pada metode ini siswa tidak dilibatkan secara aktif oleh guru dalam pembelajaran biologi. Metode diskusi yang digunakan guru dalam pembelajaran biologi adalah dengan melibatkan siswa untuk bertanya dan menjawab pertanyaan yang diberikan oleh guru biologi dan teman-temannya 
sesuai dengan materi yang diajarkan. Metode presentasi dilaksanakan guru dengan menyuruh siswa menyampaikan materi yang telah dipersiapkan siswa kemudian siswa harus menjawab pertanyaan yang diajukan oleh siswa lainnya, pada metode ini guru biologi tidak mengajarkan biologi sesuai dengan materi yang seharusnya disampaikan pada pertemuan tersebut.

Strategi pembelajaran yang dapat diterapkan adalah (1) Guru menerapkan metode belajar yang melibatkan partisipasi aktif siswa yaitu metode yang dapat meningkatkan motivasi siswa karena seluruh dimensi manusia terlibat secara aktif dengan diberikan materi pembelajaran yang konkrit, bermakna, serta relevan dalam konteks kehidupannya, (2) Guru dapat menciptakan lingkungan belajar yang kondusif sehingga anak dapat belajar dengan efektif di dalam suasana yang memberikan rasa aman, penghargaan, tanpa ancaman, dan memberikan semangat, (3) Guru memberikan pendidikan karakter secara eksplisit, sistematis, dan terkesinambungan dengan melibatkan aspek knowing the good, loving the good, and acting the good, (4) Guru menerapkan metode pengajaran yang memperhatikan keunikan masing-masing anak, yaitu menerapkan kurikulum yang melibatkan aspek kecerdasan anak (Muslich, 2011).

Pemilihan strategi pembelajaran harus disesuaikan dengan tujuan pembelajaran, kemampuan guru, kondisi siswa, sarana dan prasarana yang tersedia di sekolah (Setyaningrum, 2012). Pemilihan strategi atau metode pembelajaran yang tepat akan sangat menentukan minat dan partisipasi siswa dalam pembelajaran (Elfrida, 2007). Nilai-nilai karakter pada prinsipnya harus secara tertulis yang dicantumkan ke dalam perangkat pembelajaran dan di dalam RPP harus jelas karakter dan kompetensi dasar yang akan dimiliki oleh siswa, apa yang harus dilakukan, apa yang harus dipelajari, bagaimana mempelajarinya, serta bagaimana guru mengetahui bahwa peserta didik telah memiliki karakter tertentu.

Keberhasilan pendidikan karakter ditentukan oleh kinerja guru sebagai pelaksana pendidikan yang bertanggung jawab membekali siswa tidak hanya secara keilmuan dan keterampilan mengajar tetapi juga dibekali dengan pribadi yang berkarakter, hal ini didukung oleh Mulyasa (2011) yang menyatakan bahwa pribadi guru memiliki andil yang sangat besar terhadap pendidikan, terutama dalam pendidikan karakter yang sangat berperan dalam membentuk pribadi peserta didik. 


\section{Kendala Dalam Implementasi Pendidikan Karakter Siswa SMA Di Kabupaten Labuhanbatu Utara}

Guru memiliki peranan yang penting dalam penerapan pendidikan karakter agar siswa memiliki nilai karakter. Tetapi untuk penerapannya, guru akan mengalami kesulitan karena pendidikan karakter tidak mudah untuk diterapkan, butuh dukungan dari semua pihak seperti kepala sekolah, orang tua, masyarakat dan lingkungan.

Ketidakmampuan guru mengembangkan nilai karakter dalam pembelajaran biologi disebabkan karena kurangnya pemahaman tentang pendidikan karakter, belum adanya seminar atau workshop mengenai penerapan pendidikan karakter, dan berdasarkan hasil wawancara dari guru masih terdapat perbedaan perspektif dan konsep diantara para guru sehingga dalam pelaksanaannya terjadi keragaman. Keragaman konsep guru mengenai pendidikan karakter tersebut peneliti temukan ketika guru biologi menyatakan bahwa pendidikan karakter tidak mudah diterapkan dalam pembelajaran biologi dan guru biologi tidak mengetahui nilai-nilai karakter yang perlu dikembangkan dalam pembelajaran biologi.

Pendidikan karakter merupakan program baru yang masih menghadapi banyak kendala. Adapun kendala yang dihadapi guru dalam pembelajaran biologi yaitu (1) Sumber belajar yang belum memadai, misalnya alat dan bahan fasilitas laboratorium yang tidak lengkap, serta teknologi yang mana belum semua kelas diberikan In-focus. Untuk mengatasi masalah ini guru biologi memanfaatkan alat dan bahan yang bisa didapatkan di alam, dan juga membawa sendiri In-focus agar proses pembelajaran dapat berjalan dengan baik; dan (2) Siswa yang tidak mau menerima saran guru biologi, misalnya siswa yang tidak memerhatikan guru dalam pembelajaran biologi, siswa yang terlambat masuk ke kelas, dan siswa yang membuang sampah sembarangan. Solusi yang dilakukan guru biologi yaitu dengan memberikan peringatan dan hukuman kepada siswa, jika masih tidak dihiraukan oleh siswa, maka guru akan melaporkan siswa ke bagian bimbingan konseling (BK) untuk ditindaklanjuti.

Kendala-kendala lainnya adalah: (1) nilai-nilai karakter yang dikembangkan di sekolah belum terjabarkan dalam indikator yang representatif; (2) sekolah belum dapat memilih nilai-nilai karakter yang sesuai dengan visinya; (3) pemahaman guru tentang konsep pendidikan karakter yang masih belum menyeluruh; (4) guru belum dapat memilih nilai-nilai karakter yang sesuai dengan mata pelajaran yang diampunya; (5) guru belum memiliki kompetensi yang memadai untuk mengintegrasikan nilai-niai karakter pada mata pelajaran yang diampunya. Program sudah dijalankan, sementara pelatihan masih sangat terbatas diikuti 
guru menyebabkan keterbatasan mereka dalam mengintegrasikan nilai karakter pada mata pelajaran yang diampunya; (6) guru belum dapat menjadi teladan atas nilai-nilai karakter yang dipilihnya.

Hasil penelitian Rustaman (2011) menunjukkan bahwa dari hasil wawancara dengan guru diketahui tentang kesulitan memperkirakan waktu dan melaksanakan pembelajaran tepat waktu, karena karakter siswa bervariasi dan inisiatif siswa masih kurang, juga diketahui bahwa guru masih mengalami kebingungan untuk mengembangkan kemampuan kerja ilmiah karena tidak ada dalam kurikulum berbasis komptensi (KBK) maupun dalam kurikulum tingkat satuan pendidikan (KTSP). Mereka juga belum menyadari perbedaan pembelajaran dengan penekanan pada kompotensi dengan pada materi pembelajaran. Kendala lain yang dihadapi guru dalam penerapan pembelajaran biologi yaitu masih kurangnya kesadaran siswa untuk menaati peraturan yang berlaku, menghargai pendapat temannya, dan kurangnya motivasi belajar siswa. Kendala lainnya yaitu (1) tidak adanya pedoman yang pasti dari pemerintah/dinas dalam penerapan pendidikan karakter khususnya terkait dengan peningkatan prestasi belajar siswa, (2) faktor lingkungan siswa, (3) perkembangan teknologi yang disalahgunakan siswa dan (4) kebijakan pemerintah yang meniadakan ujian tes saat masuk sekolah.

\section{KESIMPULAN}

Guru biologi belum memahami sepenuhnya mengenai konsep pendidikan karakter. Strategi pembelajaran yang digunakan guru biologi belum menunjang untuk menanamkan nilai karakter pada siswa yaitu siswa (1) Religius, (2) Peduli Kesehatan, (3) Mandiri, (4) Bersahabat atau Komunikatif, (5) Peduli Sosial, (6) Tanggung Jawab, (7) Peduli Kesehatan, dan (8) Peduli Lingkungan. Kendala yang dialami guru biologi dalam implementasi pendidikan karakter adalah belum adanya seminar atau workshop mengenai penerapan pendidikan karakter sehinga masih terdapat perbedaan perspektif dan konsep sehingga dalam pelaksanaannya terjadi keragaman.

\section{REFERENSI}

Anonim. 2011. Pedoman Pelaksanaan Pendidikan Karakter. Badan Penelitian dan Pengembangan Pusat Kurikulum. Jakarta. 
Lapsley, D K., Narvaez, D. 2006. Character Education. Vol 4 (1). Handbook of Child Psychology (W. Damon \& R. Lerner, Series Eds.). Wiley, New York.

Mulyasa, E. 2011. Manajemen Pendidikan Karakter. Bumi Aksara. Jakarta.

Miles, M.B, \& Huberman, A.M. 1992. Analisis Data Kualitatif. Terjemahan oleh Tjetjep Rohendi R. Universitas Indonesia, Jakarta.

Muslich, M.,. 2011. Pendidikan Karakter. Bumi Aksara, Jakarta.

Paidi, H.W. 2012. Biologi, Sains, Lingkungan Dan Pembelajarannya Dalam Upaya Peningkatan Kemampuan Dan Karakter Siswa. Seminar Nasional IX Pendidikan Biologi FKPI UNS.

Rustaman, Nuryani. Y. 2011. Pendidikan dan Penelitian Sains Dalam Mengembangkan Keterampilan Berpikir Tingkat Tinggi Untuk Pembangunan Karakter. Seminar Nasional VIII Pendidikan Biologi. Prosiding Seminar. 8 (1).

Setianingrum, H. 2012. Analisis Implementasi Pendidikan Karakter dalam Pembelajaran Matematika. Jurnal Propektus. 10 (2): 206-215

Wibowo, T. 2011. Pedoman Pelaksanaan Pendidikan Karakter. Kementrian Pendidikan Nasional, Jakarta. 